\title{
OCCURRENCE OF CRYPTOSPORIDIUM SP. IN DOGS AND CATS FROM CURITIBA AND ITS METROPOLITAN AREA
}

\author{
Martha Grecca ${ }^{1}$, Vanete Thomaz-Soccol', Magda C Costa Ribeiro ${ }^{1}$, Jessé Henrique \\ Truppel $^{2}$, Juliana Tracz Pereira ${ }^{3}$, Silvia C Osaki ${ }^{4}$
}

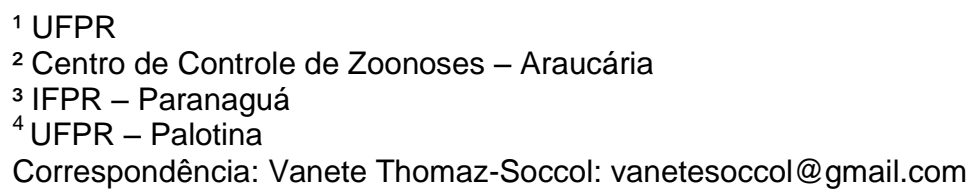

\begin{abstract}
The present study was carried out with the aim of assess the occurrence of Cryptosporidium sp. infection in dogs and cats in Curitiba and its metropolitan area, state of Paraná, Brazil. Techniques employed to detect the protozoan in fecal samples were: staining by ZiehlNeelsen for oocysts search and nested polymerase chain reaction (nPCR) targeting the 18SSU rDNA gene. To attempt the proposed aim, 91 feces samples of dogs and 25 of cats were collected and analyzed. Ziehl-Neelsen technique was unable to detect any oocyst in both groups analyzed, showing a very low sensitivity. Results of nPCR showed an infection rate of $13.2 \%(12 / 91)$ and $4 \%$ $(1 / 25)$ in dogs and cats respectively. The implications of these epidemiological data are discussed in this work.
\end{abstract}

Key Words: Cryptosporidium sp.; molecular diagnosis; nested PCR; 18SSU rDNA gene

\section{OCORRÊNCIA DE CRYPTOSPORIDIUM SP. EM CÃES E GATOS DA REGIÃO METROPOLITANA DE CURITIBA}

RESUMO: O objetivo deste trabalho foi relatar a ocorrência de Cryptosporidium sp. em cães e em gatos de Curitiba e região metropolitana, no estado do Paraná, Brasil. As técnicas utilizadas foram: coloração pelo método de Ziehl-Neelsen para detecção de oocistos e nested-PCR para pesquisa do gene 18SSU rDNA do parasito. Noventa e uma amostras de fezes de cães e 25 amostras de fezes de gatos foram colhidas. A pesquisa de oocistos pela técnica parasitológica teve resultado negativo. Na pesquisa de DNA observou-se uma taxa de positividade de 13,2\% (12/91) nas amostras fecais de cães e 4\% (1/25) nas amostras fecais de gatos. As implicações epidemiológicas destes dados são discutidas no presente trabalho.

Palavras-chave: Cryptosporidium; epidemiologia; diagnóstico molecular 


\section{INTRODUCTION}

Cryptosporidium sp. is a coccidian protozoan that belongs to the phylum Apicomplexa and has worldwide distribution, being found in 90 countries, over six continents, and infecting about 170 different species of wild and domestic animals. Some species of this protozoan have the ability to infect both man and animals, therefore Cryptosporidium can be considered a potential zoonotic parasite (O'Donoghue, 1995; Morgan et al., 2000, Cacciò, 2005; Jex et al., 2008a,b). Infection with Cryptosporidium sp. can occur by oral ingestion of infectious oocysts, through direct contact with infected people or animals, or also through ingestion in soil, food (mainly vegetables or fruit), or water contaminated with hosts feces (Amarante, 1992; O'Donoghue, 1995; Overgaauw et al., 2009; Bowman; LucioForster et al., 2010; Xiao, 2010).

Cryptosporidium canis and C. felis are the main species that infect dogs and cats (Bowman; Lucio-Forster, 2010). However, others species were also detected in these animals, such as C. parvum, C. meleagridis e C. muris (Hamnes et al., 2007; Huber et al., 2007; Bowman; Lucio-Forster, 2010). Molecular analyses have revealed that $C$. felis and $C$. canis can infect humans (Cacciò, 2005).

A recent review reported Cryptosporidium infection rates varying from $0 \%$ to $44.8 \%$ in dogs, and $0.6 \%$ to $15.4 \%$ in cats worldwide (Bowman; Lucio-Forster, 2010). In Brazil, reported prevalence for the infection vary from $1.4 \%$ to $40 \%$ in dogs and $2.8 \%$ to $30 \%$ in cats (Figueiredo et al., 2004; Ederli et al., 2005; Lallo; Bondan, 2006; Mundim et al., 2007; Thomaz et al., 2007).

In the state of Paraná, the only previous published study with Cryptosporidium infection in dogs was conducted by Navarro et al. (1997).
They detected Cryptosporidium sp. in fecal samples of dogs from the city of Londrina (north region of the state). These authors reported $2.25 \%$ of positive dogs in 133 samples that were analyzed by parasitological tests. As the prevalence data vary from one geographical region to another, the objective of this study were to survey the occurrence of Cryptosporidium sp. in dogs and cats living in the metropolitan area of the city of Curitiba, state of Paraná, Brazil using direct parasitological methods, without prior purification and concentration of the fecal samples and molecular methods in finding Cryptosporidium sp. oocysts or the parasite DNA, respectively.

\section{MATERIAL AND METHODS}

\section{Fecal samples and studied population}

Fresh fecal samples from 91 dogs and 25 cats from different shelters and veterinary clinics were collected and analyzed. Of the fecal samples from dogs, 62 were collected in Curitiba, 10 were from São José dos Pinhais and 19 from Araucária (cities in the metropolitan area of Curitiba). All samples from cats were collected in Curitiba. All cats and dogs were asymptomatic at the time of sample collection. Ages varied from 2 months to 10 years. Fecal samples were collected immediately after defecation, placed in sterile plastic bags, and kept under refrigeration $\left(4^{\circ} \mathrm{C}\right)$ until further examination, which occurred after a maximum of 48 hours.

\section{Parasitological methods}

Detection of fecal Cryptosporidium sp. oocysts was performed using acid-fast staining (Ziehl-Neelsen) (Rigo; Franco, 2002). To perform this method, thin fecal smears were directly analyzed on glass slides, without any concentration technique, and stained. Smears were analyzed under light microscopy (Olympus BX41) 
at a magnification of $40 x$. When any structure similar to Cryptosporidium sp. oocysts were observed, it was reanalyzed at a magnification of $100 x$ to confirm the diagnosis.

\section{Molecular methods}

3.1. Purification of oocysts with sucrose gradient and DNA extraction

All samples were submitted to the technique of Hoffman, Pons and Janer, as a first purification method. The supernatant was collected and then subjected to the sucrose gradient method for purification and isolation of oocysts, according to Paulino (2005). For DNA extraction, lysis buffer $(500 \mu \mathrm{L})$ was added to the purified material, which was then submitted to 15 cycles of freezing and thawing $\left(-70^{\circ} \mathrm{C}\right.$ and $\left.56^{\circ} \mathrm{C}\right)$ and then submitted to DNA extraction with magnetic beads using ChargeSwitch $^{\circledR}$ gDNA Mini Tissue Kit (Invitrogen ${ }^{\mathrm{TM}}$, Carlsbad, CA) following the manufacturer's protocol.

3.2. Polymerase chain reaction (PCR) and Nested-PCR (nPCR)

PCR analysis was performed in two different steps. The first used the pair of primes Xiao (F) 5' TTCTAGAGCTAATACATGCG 3 ' and Xiao 5'CCCATTTCCTTCGAAACAGGA3' for the Cryptosporidium sp. region of rDNA gene 18SSU. This set of primers amplifies a segment of 1325 base pairs. The second step (nPCR) was performed using as template the specific amplified products from the previous PCR with a second pair of primers Xiao $1(\mathrm{R})$ 5'AAGGAGTAAGGAACAACCTCCA 3' and Xiao $2 \quad(F)$ 5'GGAAGGGTTGTATTTA

TTAGATAAAG 3' (Xiao et al., 1999, 2000). This set of primers amplifies a segment of 826 to 864 base pairs.

The reactions of PCR and $\mathrm{nPCR}$ were standardized previously in our laboratory (Osaki, 2009). In this assay, PCR was able to amplify five oocysts, while nPCR was able to detect two oocysts (data no showed). Samples containing Cryptosporidium parvum DNA and samples without DNA (i.e., sterile water as template) were included in all the PCR reactions (as controls).

The amplification reactions were performed in a thermal cycler with a heated lid GeneAmp (Hybaid-US, Franklin, USA). Amplification products were electrophoresed in a $1.6 \%(\mathrm{w} / \mathrm{v})$ agarose gel in TBE buffer at $60 \mathrm{~V}$ for 2 h., stained with ethidium bromide (0.5 $\mu \mathrm{g} / \mathrm{mL}$ ) for $20 \mathrm{~min}$, illuminated under UV, and photographed with a UV transilluminator documentation system (Gibco BRL, Life Technologies, Grand Island, NY, USA).

\section{RESULTS AND DISCUSSION}

\section{Parasitological detection}

By direct parasitological method we could not detect any positive case for infection with Cryptosporidium sp. This negative result could be explained by the small amount of oocysts that was probably shed in the feces of the animals evaluated. According to Pereira et al. (2008), to detect Cryptosporidium sp. by Ziehl-Neelsen staining 50,000 to 500,000 oocysts per gram of feces are needed. We hypothesized that, since any cat or dog in this study had no clinical signs of disease, the amount of oocysts shed in the feces was probably too small to detect by direct parasitological methods.

\section{DNA detection ( $n P C R$ )}

Out of the 91 dogs analyzed, 12 (13.2\%) presented specific bands to Cryptosporidium sp. in nested PCR (Figure 1). Only one cat (4\%) showed a positive result (Table 1 ). The infection rates of Cryptosporidium reported in the literature varied from $0 \%$ to $44.8 \%$ in dogs and $0.6 \%$ to $15.4 \%$ in cats worldwide (Abe et al., 2002; Giangaspero et al., 2006; Funada et al., 
2007; Hamnes et al., 2007; Thomaz et al., 2007; Palmer et al., 2008; Katagiri and Oliveira-Siqueira, 2008; Meireles, 2010).

Figu re 1. Products amplified by nested-PCR containing 826 to 864 base pairs of Cryptosporidium sp. from fecal samples of dogs and cats.

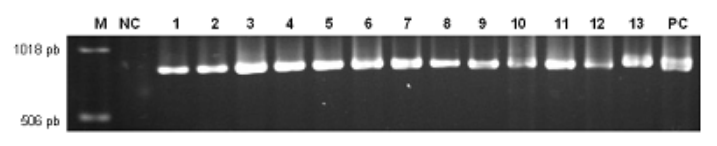

(reference st ain of C. parvum).

M: Standard molecular markes (1kb)
NC:Negative control; s smples 1 to 12 : Cryptosporidium sp. in dogs; sample 13: Cryotosporidium SP. in cat

Table 1. Nested-PCR results by counties and specie of animal studied

\begin{tabular}{cccc}
\hline City & $\begin{array}{c}\text { Samples } \\
\text { number }\end{array}$ & $\begin{array}{c}\text { Positives } \\
\text { samples }\end{array}$ & $\%$ \\
\cline { 2 - 4 } & Dogs/cats & Dogs/cats & Dogs/cats \\
Curitiba & $62 / 25$ & $7 / 1$ & $11.3 / 4$ \\
São Jose dos & $10 / 0$ & $2 / 0$ & $20 / 0$ \\
Pinhais & & & \\
Araucária & $19 / 0$ & $3 / 0$ & $15.8 / 0$ \\
\hline Total & $91 / 25$ & $12 / 1$ & $13.2 / 4$ \\
\hline
\end{tabular}

The variation of Cryptosporidium prevalence rates among dogs and cats might be due to geographic differences (temperature, season), use of different diagnostic methods, studied population, age groups and living conditions (Hamnes et al., 2007). According to Hamnes et al. (2007) other factors can affect the prevalence in animals, such as purebred/mixed breed, feeding, urban/rural living conditions, single or multiple household dogs, previous treatments, and immune status.

There is much contradiction in the literature regarding the pathogenicity of Cryptosporidium sp. in animals. In dogs, for example, some authors affirm that most infections with $C$. canis are usually asymptomatic, while others maintain that infections with $C$. canis are usually symptomatic (Hamnes et al., 2007; Smith et al., 2009). The same opposition occurs when we try to define the pathogenicity of $C$. felis in cats, since infections with $C$. felis may be asymptomatic or cause diarrhea (Smith et al., 2009). Kittens seem to be more susceptible to $C$. felis infection probably due to the immaturity of their immune system (Huber et al., 2007).

Very possibly for this reason, shedding of a larger number of oocysts is more common in young animals. Adult animals, in turn, are usually resistant to Cryptosporidium infection. However, stress conditions can favor infection with the parasite and induce shed of oocysts in older animals (Palmer et al., 2008). Molecular approaches suggest that subclinical infections may be more frequent, as shown in our study, as $13.2 \%$ of the dogs and $4 \%$ of the cats were infected with Cryptosporidium sp., but none of them showed clinical signs of the disease.

\section{CONCLUSION}

Our initial approach in this survey was to demonstrate that the parasite is definitively present in our region and is endemic. To analyze the role of dogs or cats in the transmission of Cryptosporidium to human beings it is necessary to further identify the parasite species in order to study the phylogenetic relationship in Cryptosporidium from dogs, cats and human.

\section{ACKNOWLEDGEMENTS}

We thank CAPES (Coordenação de Aperfeiçoamento de Pessoal de Nível Superior) and the graduate Program in Microbiology, Parasitology and Pathology (UFPR) for the graduate student grant, $\mathrm{CNPq}$ for the financial support.

\section{REFERENCES}

ABE, N.; SAWANO, Y.; YAMADA, K. et al. Cryptosporidium infection in dogs in Osaka, Japan. Veterinary Parasitology, v.108, n.3, p.185-193, 2002. 
AMARANTE, H.M.B. Ocorrência do Cryptosporidium sp. em indivíduos imunocompetentes e imunodeficientes em Curitiba [Dissertação]. Curitiba: Universidade Federal do Paraná, 1992.

BOWMAN, D.D.; LUCIO-FORSTER, A. Cryptosporidiosis and giardiasis in dogs and cats: veterinary and public health importance. Experimental Parasitology v.124, n.1, p.121$127,2010$.

CACCIÒ, S.M. Molecular epidemiology of human cryptosporidiosis. Parassitologia, v.47, n.2, p.185-192, 2005

EDERLI, B.B.; RODRIGUES, M.F.G.; CARVALHO, C.B. Oocistos do gênero Cryptosporidium em cães domiciliados na cidade de Campos dos Goytacazes, Estado do Rio de Janeiro. Revista Brasileira de Parasitologia Veterinária, v.14, n.3, p.129-131, 2005.

FIGUEIREDO, H.C.P.; PEREIRA-JÚNIOR, D.J.; NOGUEIRA R.B. et al. Excreção de oocistos de Cryptosporidium parvum em cães saudáveis das cidades de Lavras e Viçosa, Estado de Minas Gerais, Brasil. Ciência Rural, v.34, n.5, p.16251627, 2004.

FUNADA, M.R.; PENA, H.F.J.; SOARES, R.M. Frequency of gastrointestinal parasites in dogs and cats referred to a veterinary school hospital in the city of Sao Paulo. Arquivo Brasileiro de Medicina Veterinária e Zootecnia, v.59, n.5, p.1338-1340, 2007.

GIANGASPERO, A.; IORIO, R.; PAOLETTI, B. et al. Molecular evidence for Cryptosporidium infection in dogs in Central Italy. Parasitology Research, v.99, n.1, p.297-299, 2006.

HAMNES, I.S.; GJERDE, B.K.; ROBERTSON, L.J. A longitudinal study on the occurrence of Cryptosporidium and Giardia in dogs during their first year of life. Acta Veterinaria Scandinavia, v.49, n.1, p.22, 2007.

HUBER, F.; SILVA, S.; BOMFIM, T.C.B. et al. Genotypic characterization and phylogenetic analysis of Cryptosporidium sp. from domestic animals in Brazil. Veterinary Parasitology, v.150, n.1-2, p.65-74, 2007.

JEX, A.R.; PAGANSA, A.; CAMPBELL, B.E. et al. Classification of Cryptosporidium species from patients with sporadic cryptosporidiosis by use of sequence-based multilocus analysis following mutation scanning. Journal of Clinical Microbiology, v.46, n.7, p. 2252-2262, 2008a.

JEX, A.R.; SMITH, H.V.; MONIS, P.T. et al. Cryptosporidium - Biotechnological advances in the detection, diagnosis and analysis of genetic variation. Biotechnology Advances, v.26, n.4, p.304-317, 2008b.

KATAGIRI, S.; OLIVEIRA-SEQUEIRA, T.C.G. Zoonoses causadas por parasitas intestinais de cães e o problema de diagnóstico. Arquivo do Instituto Biológico, v.74, n.2, p.175-184, 2008.

LALLO, M.A.; BONDAN, E.F. Prevalência de Cryptosporidium sp. em cães de instituições da cidade de São Paulo. Revista da Sáude Pública, São Paulo, v. 40, n.1, 2006.

MEIRELES, M.V. Cryptosporidium infection in Brazil: implications for veterinary medicine and public health. Revista Brasileira de

Parasitologia Veterinária, v.19, n.4, p.197-204, 2010.

MORGAN, U.M.; XIAO, L.; MONIS, P. et al. Cryptosporidium spp. in Domestic Dogs: the "Dog" Genotype. Applied and Environmental Microbiology, v.66, n.5, p.2220-2223, 2000.

MUNDIM, M.J.S.; ROSA, L.A.; HORTÊNCIO, S.M. et al. Prevalence of Giardia duodenalis and Cryptosporidium spp. in dogs from different living conditions in Uberlândia, Brazil. Veterinary Parasitology, v.144, n.3-4, p.356-359, 2007.

NAVARRO, I.T.; KANO, F.S.; OGAWA, L. et al. Ocorrência de Cryptosporidium spp. em cães com diarreia atendidos no hospital veterinário da Universidade Estadual de Londrina - PR, Brasil. Semina, v.18, p.23-25, 1997.

O'DONOGHUE, P.J. Cryptosporidium and Cryptosporidiosis in Man and Animals. International Journal for Parasitology, v.25, n.2, p.139-195, 1995.

OSAKI, S.C. Cryptosporidium spp: desenvolvimento de técnicas moleculares e imunoquímicas para a detecção de oocistos em água e avaliação da sua remoção pelos métodos convencionais de tratamento da água. 2009 (Tese). Curitiba: Universidade Federal do Paraná.

OVERGAAUW, P.A.M. Zoonotic parasites in fecal samples and fur from dogs and cats in The Netherlands. Veterinary Parasitology, v.163, n.1-2, p.115-122, 2009.

PALMER, C.S.; TRAUB, R.J.; ROBERTSON, I.D. et al. Determining the zoonotic significance of Giardia and Cryptosporidium in Australian dogs and cats. Veterinary Parasitology, v.154, n.2-4, p.142-147, 2008.

PAULINO, R.C. Detecção molecular de Giardia sp em amostras fecais e água: extração de DNA genômico, PCR e RFLP. 2005. 107 f. Tese (Doutorado em Processos 
Biotecnológicos), Setor de Tecnologia,

Universidade Federal do Paraná, Curitiba.

PEREIRA, J.T.; COSTA, A.O.; SILVA, M.B.D.O. et al. Comparing the efficacy of chlorine, chlorine dioxide, and ozone in the inactivation of Cryptosporidium parvum in water from Parana state, southern Brazil. Applied Biochemistry and Biotechnology, v.151, n.2-3, p.464-473, 2008.

RIGO, C.R.; FRANCO, R.M.B. Comparação entre os métodos de Ziehl-Neelsen modificado e Acid Fast-Trichrome para a pesquisa fecal de Cryptosporidium parvum e Isospora belli.

Revista da Sociedade Brasileira de Medicina Tropical, Uberaba, v.35, n.3, p.191-193, 2002.

SMITH, R.P.; CHALMERS, R.M.; ELWIN, K. et al. Investigation of the Role of Companion Animals in the Zoonotic Transmission of Cryptosporidiosis. Zoonoses Public Health, v.56, n.1, p.24-33, 2009.

THOMAZ, A.; MEIRELES, M.V.; SOARES, R.M. et al. Molecular identification of Cryptosporidium spp. from fecal samples of felines, canines and bovines in the state of São Paulo, Brazil.

Veterinary Parasitology, v.150, n.4, p.291-296, 2007.

XIAO, L. Molecular epidemiology of cryptosporidiosis: An update. Experimental Parasitology, v.124, n.1, p.80-89, 2010.

XIAO, L.; ESCALANTE, L.; YANG, C. et al. Phylogenetic Analysis of Cryptosporidium Parasites Based on the Small-Subunit rRNA Gene Locus. Applied and Environmental Microbiology, v.65, n.4, p.1578-1583, 1999.

XIAO, L.; ALDERISIO, K.; IMOR, J. et al. Identification of species and sources of Cryptosporidium oocysts in storm waters with a Small-Subunit rRNA-based diagnostic and genotyping tool. Applied Environmental Microbiology, v.66, n.12, p.5492-5498, 2000. 